\title{
STATUS OF AVAILABLE NUTRIENTS IN SOILS SANGAMNER TAHSHIL ( AHEMEDNAGAR DISTRICT)
}

KEY WORDS: Major nutrients, Sangamner, area, Soil.

\section{Dr. Sangita Dandwate}

S.M.B. S.T College Sangamner, Department of Chemistry, Sangamner, DistAhmednagar-422605(India)

\begin{abstract}
The study area was conducted and analyzed the major and minor nutrient status of Ahemednagar district, Maharashtra. A total of 30 soil samples were collected at a depth of $0-20 \mathrm{~cm}$ and analyzed for soil $\mathrm{pH}$, electrical conductivity , organic carbon , available nitrogen (, phosphorus , potassium , Soils were neutral to slightly alkaline (pH $7.90-8.50$ ) and nonsaline (EC < l dSm 1). Calcium content from soil ranges 11.6- $28.49 \mathrm{meq} \%$ were observed. Organic carbon was low to medium with a mean value of $0.52 \%$. Among the nutrients, available Nitrogen was invariably low to moderate (100\%) and Phosphorous (25.38kg/ha) and available Potassium was generally high with a mean of $531.68 \mathrm{~kg}$ ha 1 .
\end{abstract}

\section{Introduction:}

In this process, India has become the fourth biggest fertilizer producing country. It has resulted in the leaching of a chemical into the surface and groundwater. Due to the increasing demand for cash crops, the practice of monoculture cropping pattern has further helped to deteriorate water as well as soil quality.

In recent years agriculture development has been changed from conventional and traditional farming methods too more intensive practices using chemical fertilizers and pesticides with irrigation facilities. Continuous use of chemical fertilizers slowly changed soil properties; ultimately the production in long run is reduced ${ }^{[1,2,]}$. During the last few decades, agricultural production increased due to the use of high yielding varieties and chemical fertilizers.. Therefore, it is essential to evolve and adopt a strategy of integrated nutrient supply by using a combination of chemical fertilizers, organic manures, and biofertilizers. ${ }^{[2]]}$ The concept of organic farming is getting more popular due to its eco-friendly qualities and able to sustain the soil and food quality.

\section{The study area:}

Sangamner area is located in the northern part of the Ahmednagar district of Maharashtra State. The Sangamner tahsil lies between 18036 ' $\mathrm{N}$ and 1901' N latitude and between $740 \mathrm{l}^{\prime} \mathrm{W}$ and 740 56' W longitude The area is drained by the Pravara River, which originates in the hilly region of Western Ghats at Ratangarh. Geologically, basalts underlay the Pravara basin. In general, the climate is dry and hot the average maximum temperature during summer is as high as $420 \mathrm{C}$ in the month of May and the average minimum temperature falls up to $100 \mathrm{C}$ during the month of December. The area receives rainfall, chiefly from the south waste monsoon between June and September as the area falls under the rain shadow zone of Western Ghat and receives very low precipitation.

\section{Material and Methods:}

Soils samples were collected from 45 sites covering distinct areas covered under agriculture. For study purpose area was distributed into two regions Pravara Basin and Mula Basin. The soil samples were collected from 15 villages of Sangamner tahsil to study the Physico-Chemical properties of soil. Soil sampling was done at 30 locations within the study area At each location, soil samples were collected from $20 \mathrm{~cm}$ below the surface. In all 30 soil sampling stations from the irrigated area were selected. From each station, three samples were collected. The composite surface $(0-20 \mathrm{~cm})$ soil samples were collected in the month of May 2019. While collecting soil samples the upper layer of vegetation, surface litter, stones stubble if any were cleared away and then a layer of soil immediately below $(0-20 \mathrm{~cm})$ was collected in a polythene bag. ${ }^{[3,4]}$ The 10 soil sample from various stations, Khandgaon, Nimaj, Sangamner Kh, Gunjalwadi, Ghulewadi ,Sukewadi
,Ashvi Kh,Sangavi,Jorve Kolhewadi in the summer month May 2019 Pravara region were collected.[6,7]

\section{Results and Discussion:}

This includes a set of parameters like $\mathrm{pH}$, organic matter, electric conductivity, and cation exchange capacity. The additional set of a parameter describing specific chemical elements like calcium, magnesium, nitrogen, phosphorus, potassium, etc is considered, because of adsorption is regarded as a function of physical and chemical properties of soils. ${ }^{[9,10,11]}$ The chemical analysis of the soil sample presented in Table 1

Table 1: Chemical properties of soils from Sangamner area during summer 2019

\begin{tabular}{|c|c|c|c|c|c|c|c|c|c|c|c|}
\hline $\begin{array}{c}\text { Param } \\
\text { eter }\end{array}$ & $\mathbf{S}_{1}$ & $\mathbf{S}_{2}$ & $\mathbf{S}_{3}$ & $\mathbf{S}_{4}$ & $\mathbf{S}_{5}$ & $\mathbf{S}_{6}$ & $\mathbf{S}_{1}$ & $\mathbf{S}_{8}$ & $\mathbf{S}_{9}$ & $\mathbf{S}_{10}$ & $\mathbf{n}$ \\
\hline $\begin{array}{c}\mathrm{P}^{\mathrm{H}} \\
(1: 2.5)\end{array}$ & 8. & $\begin{array}{r}8 . \\
40\end{array}$ & $\begin{array}{c}8.1 \\
9\end{array}$ & 8.40 & 8.02 & 8.40 & 8.50 & 8.21 & 8.20 & 3.31 & 8.2 \\
\hline $\begin{array}{c}\mathrm{EC} \\
\mathrm{dSm}^{-1}\end{array}$ & \begin{tabular}{|c|}
0.7 \\
8 \\
\end{tabular} & 0.41 & $\begin{array}{c}0.2 \\
6\end{array}$ & 1.10 & 4.88 & 0.81 & 2.78 & 0.94 & 59 & 85 & 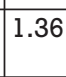 \\
\hline $\begin{array}{c}\mathrm{Ca}^{++} \\
\mathrm{meq} \%\end{array}$ & $\begin{array}{c}13 . \\
4\end{array}$ & 14.4 & $\begin{array}{l}20 . \\
32\end{array}$ & $\begin{array}{c}19.0 \\
1\end{array}$ & & & & 11.6 & $\begin{array}{c}28.4 \\
9\end{array}$ & $\begin{array}{c}22.9 \\
4\end{array}$ & $\begin{array}{r}17 . \\
8\end{array}$ \\
\hline \begin{tabular}{|c|}
$\mathrm{Mg}^{++}$ \\
$\mathrm{meq}^{+} \%$
\end{tabular} & $\begin{array}{l}16 . \\
70\end{array}$ & $\begin{array}{c}20.6 \\
7\end{array}$ & $\begin{array}{l}25 . \\
55\end{array}$ & $\begin{array}{c}14.1 \\
0\end{array}$ & $\begin{array}{c}20.0 \\
5\end{array}$ & $\begin{array}{c}14.7 \\
8\end{array}$ & $\begin{array}{c}19.0 \\
2\end{array}$ & 5.2 & $\begin{array}{c}17.2 \\
4\end{array}$ & $\begin{array}{c}15.1 \\
4\end{array}$ & $\begin{array}{c}17.7 \\
4\end{array}$ \\
\hline $\begin{array}{c}\mathrm{Na}^{+} \\
\mathrm{meq}^{2} \%\end{array}$ & $\begin{array}{c}0.3 \\
4\end{array}$ & 0.44 & $\begin{array}{c}2.3 \\
5\end{array}$ & 0.61 & 0.95 & 0.85 & .52 & 0.53 & 1.32 & .84 & 0.7 \\
\hline $\begin{array}{c}\mathrm{CaCO}_{3} \\
\%\end{array}$ & $\begin{array}{c}12 . \\
4\end{array}$ & 10.8 & $\begin{array}{c}9.1 \\
0\end{array}$ & & $\begin{array}{c}12.1 \\
1\end{array}$ & $\begin{array}{c}11.0 \\
9\end{array}$ & 8.15 & $\begin{array}{c}10.8 \\
3\end{array}$ & $\begin{array}{c}15.2 \\
4\end{array}$ & .42 & $\begin{array}{l}11 . \\
4\end{array}$ \\
\hline $\begin{array}{l}\text { rganic } \\
\text { arbon } \\
\%\end{array}$ & $\begin{array}{c}0.5 \\
2\end{array}$ & 0.45 & $\begin{array}{c}0.5 \\
0\end{array}$ & 0.58 & 0.47 & 0.55 & 51 & 0.60 & 0.41 & .55 & 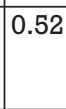 \\
\hline $\begin{array}{c}\text { Organic } \\
\text { matter } \\
\%\end{array}$ & $\begin{array}{c}0.8 \\
9\end{array}$ & 0.77 & $\begin{array}{c}0.8 \\
6\end{array}$ & 0.82 & 0.81 & 0.94 & 0.87 & 1.03 & 0.84 & 0.94 & 0.9 \\
\hline Av. N & 148 & 120. & 210 & 110. & 145. & 130. & 83.9 & 145. & 289. & 150. & 157 \\
\hline $\mathrm{kg} / \mathrm{ha}$ & .52 & 4 & .1 & 4 & 1 & 4 & 0 & 0 & 5 & 51 & 51 \\
\hline $\begin{array}{c}\text { Av.P } \\
\mathrm{kg} / \mathrm{ha}\end{array}$ & $\begin{array}{l}16 . \\
04 \\
\end{array}$ & $\begin{array}{c}10.4 \\
1\end{array}$ & $\begin{array}{l}17 . \\
24\end{array}$ & 33.0 & 28.0 & 38.6 & 31.8 & $\begin{array}{c}12.5 \\
9\end{array}$ & 16.0 & 31.6 & \\
\hline Av.K & 365 & 390. & 611 & 370 & 509. & 770. & 312. & 610. & 680. & 693. & 531 \\
\hline /ha & .11 & 2 & .7 & 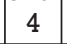 & 6 & 4 & 0 & 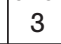 & 0 & 65 & 6 \\
\hline
\end{tabular}

The soil $\mathrm{pH}$ determined by Potentiometric $\mathrm{pH}$ meter having a combined glass electrode and reference electrode using 1:2.5 soil: water suspension ratio. ${ }^{[12]}$ Soil analysis of Pravara from the irrigated area all soil samples the $\mathrm{pH}$ was observed above 7. It ranges from 7.90 to 8.50 reflecting the alkaline nature of soils. It is observed in a narrow range of variation in $\mathrm{pH}$ in the area. (Table 2) Based on the above classification criteria the study area soils showed normal pH. Soil showed lower values were reported from Sadatpur (S13), Umbaribalapur (S14), and higher values from Nimaj, Gunjalwadi, Sangavi, Sukewadi, Rahimpur (S2, S4, S6, S7, S1 1) 
in irrigation areas from the Pravara basin. Electrical conductivity (EC) indicates the total soluble salts content of the soils. It is used as a rapid method of appraising soil salinity ${ }^{[17,18]}$ Soils from the Pravara basin, irrigation area EC values range from 0.26 to $4.88 \mathrm{ds} / \mathrm{m}$. in the study area, the higher values of EC obtained soil no S4, S5, S7, S9, S10, S1 1, in this area particularly at Jorve, Kolhewadi, Rahimpur, transportation of salts with surface runoff is negligible. Electrical conductivity rated soil are categorized as normal $(\mathrm{Ec}<1 \mathrm{mmhos} / \mathrm{cm})$

During this process, the cations of the clay / colloidal matter are exchanged in equivalent quantities with the cations of soil and salt solution. This process of exchanges of the cation of soil and salt solution is known as cation exchange. In the study area, Pravara basin cations from the soil have been calculated. ${ }^{[5]}$ The calcium ranges from irrigated area 11.6 to $28.49 \mathrm{meq} \%$ and magnesium 11.60 to $25.55 \mathrm{meq} \%$.The soils in semi-arid and arid climate usually the area show precipitation of calcium carbonate. Caco3 content from soil ranges between 8.15 to $16.13 \%$ in the irrigated area of the Pravara basin. From the above data given in the table the majority of the soil $(66.67 \%)$ are strongly calcareous and $33.33 \%$ soil moderately calcareous soil in the Pravara basin, region irrigated area. The data given in Table 2 shows that organic carbon ranges from 0.45 to $0.63 \%$ in the irrigation area. The plant absorbs nitrogen either ammonium or nitrate ions. Orlov (1992) reported that the transformation of the nitrogen compounds in the soils involves the following process ${ }^{[1]]}$. The available nitrogen in the Pravara basin the soil ranges from 83.90 to $289.54 \mathrm{~kg} / \mathrm{ha}$ in irrigated area. ${ }^{[20]}$ Potassium is a major nutrient for the production of superior quality crop some of the important functions The available potassium content ranges from Pravara basin 312.20 to $770.0 \mathrm{~kg} / \mathrm{ha}$ in irrigated area. The majority of the soil samples show high to very high available potassium while few samples showed moderate to moderatehigh available potassium in the three areas. The soil of Marathawada contained high to medium available potassium. ${ }^{[13]}$ Phosphorus is called the master key element in soil quality equation. ${ }^{[14,15]}$ In the study area phosphorous ranges from 12.59 to $38.60 \mathrm{~kg} / \mathrm{ha}$ irrigated area.

\section{Conclusion:}

The generated nutrient status information can serve as an effective tool for farmers and policymakers in the adoption of site-specific nutrient management practices.

Classification criteria the study area soils showed normal $\mathrm{pH}$. The exchangeable cations present in agricultural soil are $\mathrm{Ca}^{2+}, \mathrm{Mg}^{2+}, \mathrm{Na}^{++} \mathrm{K}_{+}$. All cations, $\mathrm{Ca}^{2+}$ are maximum replacing capacity while $\mathrm{Na}+$, has a minimum, because $\mathrm{Ca}^{2+}$, has greater valency and a smaller hydrated radius than that of $\mathrm{Na}+$, as a result of this proportion of these ions on the colloidal surface constantly changes depending upon the ions added from the dissolving minerals, fertilizer, gypsum, etc. Conclusively from irrigation areas, soil samples show a medium proportion of organic carbon. The higher nutrient fertility status in irrigation fields might be associated with intensive cultivation and plantation of cash crops like sugarcane, cotton, fruit crops, etc. in which use of fertilizers as practiced by the cultivators

\section{Acknowledgements:}

We are very sincerely thankful to everyone who supported us. We are thankful for their moral support valuable guidance during this work. This work is for farmer related work so we devote this work to the farmer and very glad to inform. I am very thankful to farmer those who help me and my college staff those who encourage me for this work.

\section{References:}

[1] Barhate, C. L. (1971) The physico-chemical properties of the soils of Ahmednagar district and the fertility status as influenced by agri-climatic differences, M.Sc. (Agri) dissertation, MPKV, Rahuri, Ahmednagar dist., Maharashtra.
[2] Bharambe, P.R., and Ghonsikar, C. P. (1984). Fertility status of soils in Jayakwadi Command.J.Maharashtra agric.Univ.9(3):326-327.

[3] Bharambe, P. R. and Ghonsikar, C. P. (1985). Physico-chemical characteristics of soils in Jayakwadi Command.J. Maharashtra Agric. Univ. 10:247-249.

[4] Bhattacharya, T., Deshmukh, S.N., and Roychaudhary, C. (1989). Soils and land use of Junnar Tahasil, Pune district, Maharashtra.J. Maharashtra Agric. Univ. 14 (1): $1-4$

[5] Biswas, B.C., Yadav, D.S., and Maheshwari, S. (1985). Role of calcium and magnesium in Indian agriculture. A Rev., ferti.News, 30: 15-35.

[6] Black, C.A. (1965). Method of soil analysis. Part 2 Inc. Publi; Madison, Wisconsin, USA.Pp

[7] Chopra, S.L., and Kanwar, J.S. (1991). Analytical Agricultural Chemistry. Kalyani publi;New Delhi, Ludhiana

[8] Dahama, A.K. (2002). Organic farming, on the overview for sustainable agriculture. Second Enlarged Edition. Agrobios (India) Jodhpur.

[9] Daji, J.A. (1998). A textbook of Soil Science. Media promoters and publi. Bombay:pp 1-365

[10] Gaibe, M.V., Lande, M.G. and Varade S.B. (1976). The soil of Marathwada. J. Maharashtra Agric. Univ. 1(2-6):55-59.

[11] Hausenbuiller,R.L. (1976). Soil science, Principles, and practices, Washington State University, Pullman pp 247.

[12] Jackson, M.L. (1973). Soil chemical analysis. Prentice-Hall of India,New Delhi.

[13] Kachhave, K.G., and More, S.D. (1982). Research notes available potassium status in relation to physicochemical properties of Maharashtra soils. J. Maharashtra Agri.Univ. 7(2): 1- 178.

[14] Miller, R.W and Donahue, R.L. (1992). Soils an introduction of soils and plant growth. 6th Edition prentic hall of India Pvt.Ltd:New Delhi.

[15] Olsen, S.R., Cole, C.V., Watanbe, F.S., and Dean, L.A. (1954). Estimation of available phosphorous in soil by extraction with sodium bicarbonate circ, U.S. Dept Agri: 939

[16] Orlov,D.S. (1992). Soil Chemistry, Oxford and IBH publi.Co,New Delhi.

[17]. Piper, C.S. (1966). Soil and plant analysis. Hans publi, Bombay.

[18]. Richards, L. A. (1968). Diagnosis and improvement of saline and alkali soils. U.S. Salinity Laboratory Staff, Agriculture handbook No. 60, Oxford and IBH Publi.Co.New Delhi

[19] Somwanshi, R.B., Kadu, P.P; Tamboli, B.D; Patil, Y.M. and Bhakare, B.D.(1999). Analysis of plants, irrigation water, and soils MPKV. Extn. Publ. No. 284. Rahuri (Maharashtra).

[20] Subbiah, B.V.and Asija, G.L.(1956). A rapid procedure for the determination of available nitrogen in soils. Curr. Sci. 25:254-260.

[21] Swaminathan, M.S. (1985). Biofertilizers in agriculture and forestry. 3rd edn publi. Mohan primiani for oxford and IBH publishing Co. Pvt. Ltd.66 Janpath New Delhi. 